\title{
THE FOUR LEAF WATER CLOVER (MARSILEA QUADRIFOLIA L.) AN ENDANGERED SPECIES. ASPECTS OF CONSERVATION AND MANAGEMENT
}

Erika SCHNEIDER-BINDER *

* University of Land Baden-Württemberg and Research Centre of the Helmholtz Society, Karlsruhe Institute for Technology, Institute for Geography and Geoecology, Department WWF-Institute for Floodplain Ecology, Josef Strasse 1, Rastatt, Germany, D-76437, erika.schneider@kit.edu; erika.schb@t-online.de

DOI: 10.1515/trser-2015-0011

KEYWORDS: ecological requirements, endangered by extinction, extinct in the wild, competition capacity, conservation management.

\section{ABSTRACT}

The European species of the genus Marsilea are presented, with special regard to Four leaf water clover Marsilea quadrifolia L., the single species occurring in Central Europe. Based on field research on the Upper Rhine in Germany and the Lower Danube in Romania the ecological requirements of the species and the plant communities in which the species lives are analysed and compared with data from other European countries. Due to the decline of the species populations as a consequence of human activities, all European Marsilea species are rare, vulnerable, endangered by extinction or extinct in the wild and included in the Red data books of most European countries. Also all the European water clovers Marsilea strigosa, Marsilea batardae and Marsilea quadrifolia have been included in the Appendix I of the Bern Convention (1979) as strictly protected species and in the Annexe II of the European Flora Fauna Habitat Directive 92/43/1992. After analysis of ecological conditions, the state of conservation and the Red List categories of Marsilea quadrifolia following IUCN criteria in the countries of occurrence are presented and possible measures for conservation are discussed as well as realised reintroduction of the species in the wild.

ZUSAMMENFASSUNG: Der Kleefarn (Marsilea quadrifolia L.) eine bedrohte Art. Aspekte betreffend Schutz und Management.

Die europäischen Arten der Gattung Marsilea werden unter besonderer Berücksichtigung des Kleefarns Marsilea quadrifolia L., der einzigen in Mitteleuropa vorkommenden Art, untersucht. Auf Grund eigener Feldforschung am Oberrhein und an der Unteren Donau werden die ökologischen Ansprüche der Art und ihre Vergesellschaftung dargelegt und mit Angaben aus anderen europäischen Ländern verglichen. Bedingt durch die Verringerung der Populationen infolge menschlicher Tätigkeiten sind alle europäischen Arten der Gattung Marsilea selten, gefährdet, vom Aussterben bedroht oder bereits ausgestorben und in die Roten Bücher bzw. Listen fast aller europäischen Länder aufgenommen worden. Ebenso sind alle europäischen Kleefarnarten Marsilea strigosa, Marsilea batardae und Marsilea quadrifolia als streng geschützte Arten in Anhang I der Berner Konvention (1979) und Anhang II der Flora-Fauna-Habitatrichtlinie 92/43/1992 gelistet. Nach einer Analyse der ökologischen Ansprüche und des Erhaltungszustandes der Art sowie ihrer Einordnung in eine bestimmte Schutzkategorie in den einzelnen Ländern nach IUCN Kriterien, werden mögliche Schutz- und Erhaltungsmaßnahmen sowie bereits durchgeführte Maßnahmen zur Wiedereinbürgerung besprochen. 
REZUMAT: Trifoiaşul de baltă (Marsilea quadrifolia L.), o specie periclitată. Aspecte de conservare şi management.

Lucrarea prezintă speciile europene ale genului Marsilea, cu privire specială asupra trifoiaşului de baltă Marsilea quadrifolia L., singura specie cu răspândire în Europa Centrală. În baza cercetărilor pe teren în regiunea Rinului superior în Germania şi a Dunării inferioare din România sunt analizate cerințele ecologice, precum şi comunităţile de plante în care creşte specia şi sunt comparate cu datele din alte ţări europene. Datorită reducerii populaţiilor în urma impactului antropic, toate speciile europene ale genului Marsilea sunt rare, vulnerabile periclitate prin extincţie sau deja dispărute, fiind cuprinse în Cărţile roşii, respectiv Listele roşii ale majorităţii ţărilor europene din care se cunoaşte specia. De asemenea, toate speciile europene de trifoiaş de baltă Marsilea strigosa, Marsilea batardae şi Marsilea quadrifolia sunt listate ca specii strict protejate în Anexa I a Convenţiei de la Berna (1979) şi în Anexa II a Directivei Floră-Faună-Habitate 92/43/1992. După analiza cerințelor ecologice şi a stării de conservare a speciei, precum şi a încadrării ei în anumite categorii de protecţie în diferitele țări europene conform criteriilor UICN, sunt discutate posibile măsuri de protecţie şi de conservare, precum şi măsuri de reintroducere a speciei în zonele din care a dispărut.

\section{INTRODUCTION}

The genus Marsilea (Fam. Marsileaceae/Pteridophyta), including worldwide about 45 species of aquatic plants in tropical and warm regions (Cook, 1996), is represented in Europe by four species: Marsilea quadrifolia L., Marsilea strigosa Willd., Marsilea batardae Launert and Marsilea aegyptica Willd. All are hydro-helophytes or hygrophytes occuring mostly in standing, shallow permanent or temporary, sometime drying-out waters, in ponds, ditches and locally in ricefields. Due to the decline of the species as a consequence of human activities such as drainage and water pollution, all European Marsilea species are Rare, Vulnerable, Endangered by extinction or Extinct in the wild and included in the Red data books of most European countries. Of the four species mentioned, Marsilea batardae Launert is rare and endemic to the Iberian Peninsula (Medina et al., 2004; Banares et al., 2004). Marsilea aegyptica Willd. has been mentioned only from the Lower Volga area as a rare species with a disjunct distribution area (Tahtadjian et al., 1988). Marsilea strigosa Willd. is a Mediterranean species with pubescent leaves that occurs in Southern Europe, being mentioned from Italy (Conti et al., 1992), Southern France (Dehondt et al., 2005) and South-western Spain (Garcia et al., 2006; Banares et al., 2010). The species have been mentioned also from the Lower Volga area, but has been regarded as extinct in recent decades (Tahtadjian et al., 1988; Conti et al., 1992). The Four leaf water clover (named also Water Shamrock) Marsilea quadrifolia L., an Euroasiatic species, distributed over a larger area with prevailing small populations, is the single species of the genus Marsilea occurring in Central Europe.

Following the data from older publications and comparing them with recent data of the species, there has been observed a decrease in its distribution area, with it being extinct in many sites, considered in others as endangered by extinction or as a vulnerable species. This is why all the water clovers of the European Union - Marsilea strigosa, M. batardae and $M$. quadrifolia - have been included in the Appendix I of the Convention on the Conservation of European Wildlife and Natural Habitats/Bern Convention (1979) as a strictly protected species and in the Annexe II of the European Flora Fauna Habitat Directive 92/43/1992 including the animal and plant species of community interest whose conservation requires the designation of special areas. 
The object of this paper is to follow the actual distribution of the water clover Marsilea quadrifolia L. in Europe on the basis of data from different countries and our own research data, to compare the ecological and phytocoenological data of the species from different regions of Europe as well as the conservation status and type of management measures. At the same time we discuss the applicable and needed measuers to conserve the species in the still existing sites and to find out - knowing the ecological requirements of the species - the appropriate sites for reintroduction or revitalization of stands, if sporocarps of the species persist in the area.

\section{MATERIAL AND METHODS}

On the basis of our own field research are presented data of Marsilea quadrifolia populations on the Upper Rhine (2009), the Lower Danube Giurgiu/Slobozia area (2004) and the Danube Delta (Rusca Polder 1993, Sfântu Gheorghe 2011) the ecology, phytocoenology and conservation status, human impacts and their consequences. The plant communities identified by Marsilea quadrifolia and the surrounding vegetation has been studied on the Rhine and on the Danube on the base of transects along ecological gradients with side-by-side phytocoenological sampling according to the method of Braun-Blanquet (1964). On the Rhine the sampling was realised within the framework of the Management Plan for the Natura 2000 Site "Floodplain of the Rhine between Iffezheim and Karlsruhe" (experimental plots 4 and 5).

The ecological and phytocoenological data are compared with those from literature concerning the species from other European countries. Possible management measures are discussed on the basis of the analysed field and literature data.

\section{RESULTS AND DISCUSSION}

Site conditions and distribution area.

The actual occurrence of Marsilea quadrifolia is related partly to natural water bodies such as oxbow lakes, flood channels and partly to man-made water bodies such as fishponds (Landolt, 1991; Dehondt et al., 2005; Schneider et al., 2005; Benedek et al., 2012) ricefields (Felföldy, 1990; Conti et al., 1992; Benedek et al., 2012), clay-pits (Landolt, 1991), gravel exploitation places, ditches with slowly running waters (Conti et al., 1992; Käsermann, 1999) and artificial lakes (Conti et al., 1992; Ramsar Information Sheet, 1998). The waters are mostly shallow and dry out temporary.

The species is mentioned as growing on muddy ground, clay-sandy or sandy soils (Käsermann, 1999; Oberdorfer, 2001; Tahtadjian et al., 1988), but it is also mentioned from marshy soils, rich in organic matter (Dehondt et al., 2005). In two cases the occurrence of the species is mentioned in relation to old pig pastures with open places free of vegetation (Käsermann, 1999; Pouchol, 2000; Oberdorfer, 2001; Philippi, 1969) as well as from hempand flax-steeping places (Philippi, 1969).

Concerning the nutrient content of the waters in which the species grows, occurrences are known in oligotrophic, oligo-mesotrophic and mesotrophic nutrient and humus-poor waters (Käsermann, 1999; Pouchol, 2000; Dehondt et al., 2005; Bundesamt für Naturschutz, 2012), but also nutrient-rich sites (Oberdorfer, 2001; Schneider, 1993; field sampling in the Danube Delta, Rusca area). But a strong eutrophication in sites with Marsilea quadrifolia is the cause of decline of the species populations (Pouchol, 2000). The waters in which the species occurs are frequently measured as deficient in calcium carbonate (Landolt, 1991; Oberdorfer, 2001) and Marsilea quadrifolia is considered to be a calcifuge (Dray, 1985). 
According to our observations Marsilea quadrifolia occurs also in conditions of light to medium salinity, growing in the Danube Delta (Sf. Gheorghe) together with typical halophilous species. As a water macrophyte, the species occurs together with Azolla filiculoides, which indicates a light salinity. Under terrestrial conditions the species has been observed growing in the neighbourhood of Juncus maritimus and Limonium meyeri, typical halophilous species, as well as species indicating a light salinity such as Pulicaria dysenterica, Trifolium fragiferum, Mentha pulegium, Cynodon dactylon and Tamarix ramosissima. Similar conditions with those in the Danube Delta at Sf. Gheorghe, living on sandy saline substrate are mentioned for Marsilea strigosa from the Lower Volga area (Tahtadjian et al., 1988).

The water clover is known as a species with low concurrence capability which is related to tolerance towards different ecological factors (Felföldy, 1990; Horváth et al., 1995; Käsermann, 1999; Pouchol, 2000; Dehondt et al., 2005). As a heliophilous species without tolerance to shade, the water clover is quickly eliminated in the course of succession by higher growing and overshadowing species (Dehondt et al., 2005; Käsermann, 1999; Pouchol, 2000). It seems the species sometimes needs light disturbances related to human interventions which keep open the sites where Marsilea quadrifolia can establish without competition from other species (for example old pig pastures). These factors are near the trophic conditions strong limiting factors for the repartition of the species.

\section{Geographical distribution}

On the Iberian Peninsula the species occurred in wetlands on the Mediterranean coast, but at present is considered as extinct in the wild, being reintroduced in the Delta of the Ebro River (Aedo et al., 2012). In Portugal Marsilea quadrifolia being at present in a critical situation with strong regression it is mentioned in small area of Douro and Trás-os-Montes (ICN, 2006).

In France Marsilea quadrifolia is mentioned from the Centre of France in the plain of the Loire and Allier rivers, in the regions of Anjou, Touraine, Orléans, Sologne, Brenne, les Dombes, Lyon and in the Eastern France region of Franche-Comté: Bresse Comtoise, Piedmont of Vosges and the Sundgau near Belfort (Dehondt, 2005; Dehondt et al., 2005). In the last mentioned localities of the Franche-Comte region, the species occurs in a number of fishpond areas.

In Switzerland Marsilea quadrifolia is still mentioned from the "Pruntruter Zipfel" near Bonfol/region of Jura (Landolt, 1991; Käsermann, 1999) near to the locations of FrancheComté in France. In all other localities known from older data in Switzerland, the species has disappeared.

In Italy this thermophilous Eurasian species is mentioned from sea level to $400 \mathrm{~m}$ altitude occurring in the Piemont area on the upper Po River and reaching to South in the area of Naples (Napoli), these localities being the most Southern of the distribution area in Europe (Conti et al., 1992).

In Germany Marsilea quadrifolia occured only on the Middle and Northern Upper Rhine, but apart from the existence in one location, in all the others mentioned as existing before 1945 (Haeupler and Schönfelder, 1988) the species is considered at present as extinct. In 1986 the Four leaf water clover has been registered South of Karlsruhe between the localities Mörsch and Neuburgweier (Rheinstetten) in the old floodplain of the river Rhine, in a location named Rösteläcker. As the species stands decreased more and more, being repressed through succession by species more competitive such as Reed (Phragmites australis) and Reed-mace (Typha angustifolia) the water clover disappeared. As the 
species were known in the area from old pig pastures as well as hemp- and flax-steeping places, in 2002 a pig pasture area has been established in the area of Rösteläcker/Rheinstetten, South of Karlsruhe (Radkowitsch, 2006). One year later in 2003 a new occurrence of Marsilea quadrifolia has been registered in a flashing area of a gravel extraction place near Lahr. From this location plant material were taken out and started-up a "conservation culture" in the Botanical Garden of the University Karlsruhe (Radkowitsch, 2006, 2007; Waitzmann and Schweizer, 2009). The last at present existing distribution point of the species in Germany on the Upper Rhine is the result of a recent reintroduction of the species in the wild.

In Poland, where the species exists at the Northern limit of its area, it is mentioned as extinct in the wild, but cultivated in the Botanical Garden of Warsaw University and reintroduced into a pond at the Bolestraszyce Arboretum near Przemysl (Kazmierczskowa and Zarzycki, 2001; Zarzycki and Szelag, 1992). From this place some of the individuals were transplanted to two reservoirs in the environment of Pulawy (Kazmierczskowa and Zarzycki, 2001). According to newer data, the species exists still in the Botanical Garden of Warsaw.

The map of occurrence of species Marsilea quadrifolia shows for the area of former Czechoslovakia only localities in the Eastern Slovakian lowland on the Latorica River (Husák and Otahelová, 1986), near to the area of the Ukrainian occurrences in Zakarpatia area (Shelijag-Sosonka, 1996). In the past Marsilea quadrifolia has been found in Slovakia also in the area of Bodrog, Laborec and Uh rivers (Botanix, 2012). The mention of Marsilea quadrifolia as occurring in the Czech Republic (IUCN, 2012) refers to the old literature data for Czechoslovakia, and are related to the distribution points in Eastern Slovakia.

In Austria the species is extinct in most of its former known localities, existing at present only in Styria/Steiermark in the Southeastern part of the country (Adler et al., 1994; Käsermann, 1999).

The distribution map of the species Marsilea quadrifolia in Hungary indicates localities between the Danube and the Tisza/Tisa rivers in the large Hungarian Plain, the so called "Alföld", were the species occurs in the area of ricefields that from time to time dry out (Felföldy, 1990).

In Croatia the distribution map shows many locations along the Sava River (Borsic, 2012) and also some points on the Drava River, but most are from older literature data, only a few of the localities having recent confirmation by field research. The localities, where the Water clover occurs at present are strongly related to the pig pasturing as traditional activity in the Sava floodplain area, which in its turn is related to the Sava old oak hardwood floodplain forests area. In the floodplain used as pig pasture, there are locally large areas covered by Marsilea quadrifolia (oral communication by Mr. Damm C., 2011).

Marsilea quadrifolia is also listed in The Red Book of the Albanian flora (Vangjeli et al., 1995), as well in the Red Books for Bosnia and Herzegovina (Silic, 1996).

In Bulgaria, Marsilea quadrifolia species is mentioned in the Danube Plain from two sites, the Tracian lowland in Southern Bulgaria and the Strumska Valley (Dakov, 1984) occurring in permanent or temporary water bodies, swamps and rice cultures on muddy underground.

In Greece the species is mentioned as very rare, on the border of the artificial Lake Kerkini (Ramsar Information Sheet, 1998). 
In Romania, the species records are published from different parts of the country (Topa, 1952). The localities are concentrated in the lowland area of the Western Plain, Oradea and Salonta area, the Southern part of the Crişuri region, and the lower Mureş and Timişoara area. Given as well are localities on the Danube (Ostrovul Corbului/Turnu Severin, Brăila) and lakes of the Romanian Plain around Bucharest as well as two points in Dobrogea, but at that time (1952) no data about the occurrence of the species existed for the Danube Delta. Mentioned are also in the older literature data for the Transylvanian Tableland, the so-called "Câmpia Transilvaniei", but these points were not confirmed at the middle of the 20th century (Topa, 1952). From many of the localities in which Marsilea quadrifolia was found six decades ago (Topa, 1952) the species has disappeared, while others are reconfirmed (Oprea, 2005) and some new locations has been discovered in the last years. On the Lower Danube the species exist at present in a partly abandoned fish pond area near Slobozia/Giurgiu (Schneider et al., 2005). In the Danube Delta the species is mentioned as rare (Ciocârlan, 1994) and described from the fishpond area of Rusca and on the mouth of Sulina branch into the Black Sea (Oţel, 2000). Recently (2011) the species were found at Sfântu Gheorghe near to the coast of the Black Sea in stands with high abundance-dominance and represented by Marsilea quadrifolia L. f. natans Kaulf. and f. terrestris Hayek (Tab. 2, Figs. 1 and 2).

The distribution map of Marsilea quadrifolia in Ukraine shows a concentration of some localities North of the Chilia/Kilija branch of the Danube Delta, on the lower and upper Dniester/Nistru, on the Southern Bug, in the Zakarpatia region of Western Ukraine and area of the Shatski Lakes part of Polessie Swamps (Shelijag-Sosonka, 1996).

\section{Phytoceonological remarks.}

Marsilea quadrifolia is mostly considered as a native accessorial species occurring in communities of the Class Isoeto-Nanojuncetea Br.-Bl. et Tx. 1943 (Kazmierczakowa and Zarzycki, 2001; Horváth et al., 1995; Dehondt et al., 2005) order Isoetetalia (Borsic, 2012) or order Cyperetalia fusci, alliance Nanocyperion flavescentis (Felföldy, 1990; Dehondt et al., 2005; Oberdorfer, 2001) or in the class of Litorelletea uniflorae Br.-Bl.et Tx. 1943, alliance Eleocharition acicularis (Dehondt et al., 2005; Oberdorfer, 2001). The occurrence together with Elatine triandra, characteristic for the order Cyperetalia fusci as well as with Limosella aquatica, Cyperus fuscus, Juncus bulbosus and Lindernia procumbens documents the affinity to communities of the alliance Nancyperion/Order Cyperetalia fusci/class IsoetoNanojuncetea. But the observed association with the species Utricularia australis, Trapa natans, Myriophyllum spicatum, and Phragmites australis (Dehondt et al., 2005) speaks for the affinity to communities of the class Potamogetonetea pectinati Klika 1941.

In Spain is mentioned the affiliation to the Class Oryzetea sativae (Banares et al., 2004).

The studied area in the plain of the river Rhine South of Karlsruhe and the samples from this area shows on the one side the identification of communities which are characteristic for Potamogetonetea (Tab. 1, column 1-6) interfering with Phragmitetea species and on the other side the integration in a pioneer community with species of the alliance Nanocyperion (Tab. 1, column 7-10) such are Cyperus fuscus and Centaurium pulchellum. The distinction is based on the different depth of the generally shallow water body. The first group is characteristic for the "deeper" part of the water body and the second for the edge of the water which is more rapidly falling dry as the other part. The entire water body can dry out, but the time period is different. The covering degree of Marsilea quadrifolia is locally very high, but also Potamogeton nodosus reaches a high covering degree in some phytocoenoses of the area (sample 4). As this species is more competitive it can be a threat to the water clover with less competition capacity. 
Table 1: Phytocoenoses of Marsilea quadrifolia near Rheinstetten South of Karlsruhe, in Germany.

\begin{tabular}{|l|c|c|c|c|c|c|c|c|c|c|}
\hline & & & & & & & & & & \\
\hline Number of sample & 1 & 2 & 3 & 4 & 5 & 6 & 7 & 8 & 9 & 10 \\
\hline & & & & & & & & & & \\
\hline Cover degree in \% & 85 & 85 & 100 & 70 & 45 & 25 & 25 & 45 & 40 & 45 \\
\hline & & & & & & & & & & \\
\hline Marsilea quadrifolia floating leafs & 4 & 4 & 5 & 1 & 3 & 2 & 2 & 3 & + & + \\
\hline Marsilea quadrifolia & 2 & + & - & - & - & - & - & - & - & - \\
\hline Alisma plantago-aquatica & - & - & - & + & - & - & + & + & - & - \\
\hline Lythrum salicaria & - & - & - & - & - & - & + & - & - & - \\
\hline Salix purpurea & - & - & - & - & - & - & + & + & - & - \\
\hline Cyperus fuscus & - & - & - & - & - & - & - & - & 3 & 3 \\
\hline Equisetum palustre & - & - & - & - & - & - & - & - & + & + \\
\hline Potamogeton nodosus & + & 2 & - & 4 & - & + & - & + & + & - \\
\hline Centaurium pulchellum & - & - & - & - & - & - & - & - & - & 1 \\
\hline Schoenoplectus lacustris & - & - & - & - & - & - & - & - & - & + \\
\hline Alopecurus geniculatus & - & - & - & - & - & - & - & - & - & + \\
\hline Agrostis stolonifera & - & - & - & - & - & - & - & + & + & + \\
\hline Butomus umbellatus & - & - & - & - & 1 & - & - & - & - & - \\
\hline Chara vulgaris & - & - & - & - & - & + & - & - & - & - \\
\hline & & & & & & & & & & \\
\hline Place and data of sampling & & & & & & & & & & \\
\hline Rösteläcker, Rheinstetten/Karlsruhe 31.07 .2009 & & & & & & & \\
\hline
\end{tabular}

Other phytocoenological aspects can be observed for the studied site in the dune area of Sfântu Gheorghe in the Danube Delta (Tab. 2, Figs. 1 and 2). Marsilea quadrifolia is associated with floating aquatic macrophytes such as Hydorcharis morsus ranae, Salvinia natans, Spirodela polyrhiza, Lemna minor, Lemna trisulca characterstic for communities of the alliance Lemnion minoris Tx. 1955, classe Lemnetea minoris Tx. 1955 and rooted water macrophytes such are Nymphoides peltata characteristic for the alliance Nymphaeion albae Oberd. 1957, class Potamogetonetea pectinati Klika 41 (Tab. 2, column 1-6). The water clover presents furthermore in the site at Sfântu Gheorghe a larger surface of terrestrial stands (Tab. 2, column 7-10), which are in contact with reed communities edified by Sparganium ramosum, Typha angustifolia and the halophilous species Juncus maritimus and Limonium meyeri as well as grassland species characteristic for light salinity in the soil. In the area of Rusca polder/Danube Delta where the species occurs sporadically in shallow drying out waters (fishponds) no accompanying species has been observed.

On the Lower Danube near Slobozia upstream of the town of Giurgiu Marsilea quadrifolia has been observed (June 2004) in an abandoned fishponds area as growing in interference with stands of Typha angustifolia. 


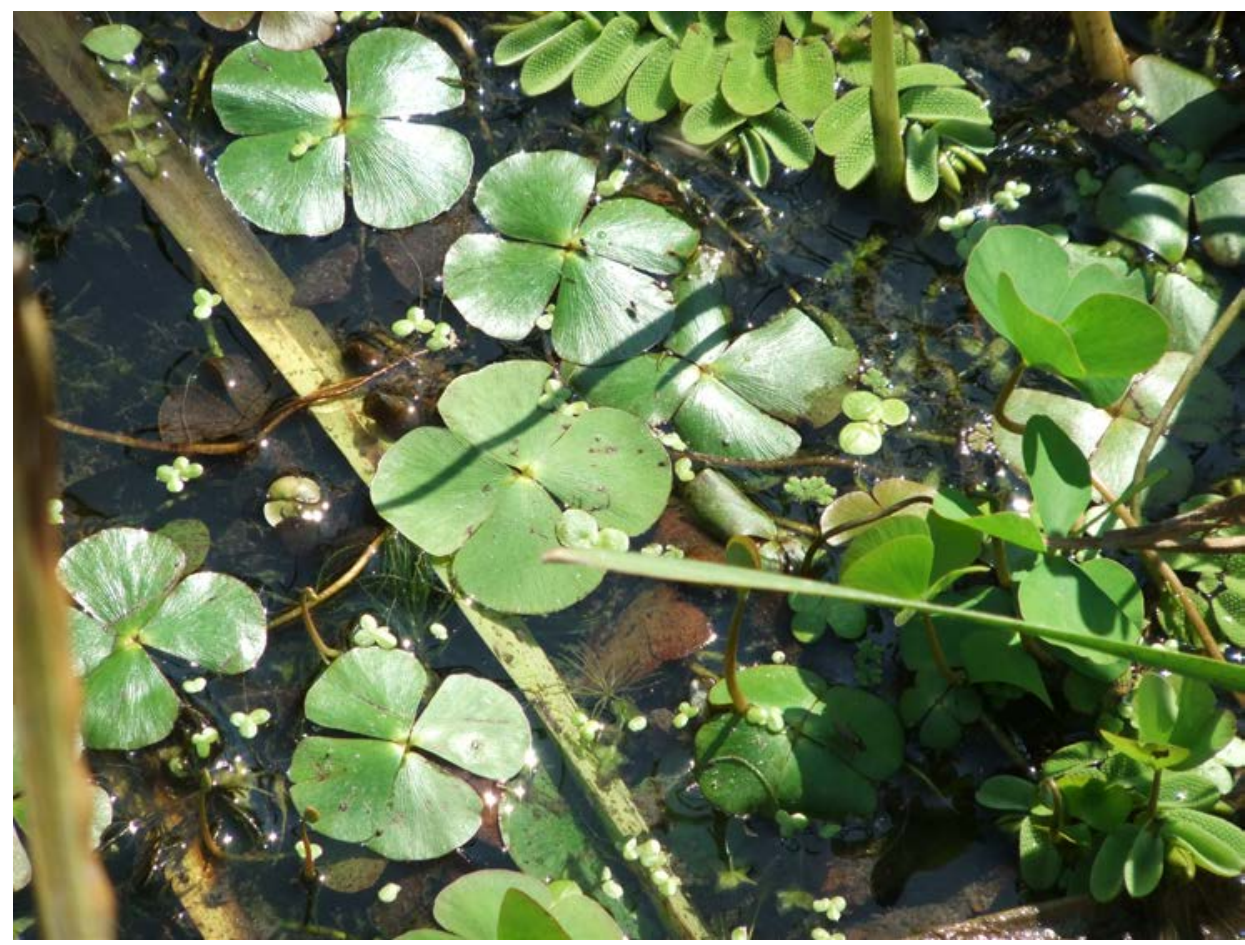

Figure 1: Marsilea quadrifolia L. with Spirodela polyrhiza, Salvinia natans, Lemna minor, Lemna trisulca, Azolla filiculoides (Danube Delta, Sfântu Gheorghe, 2011).

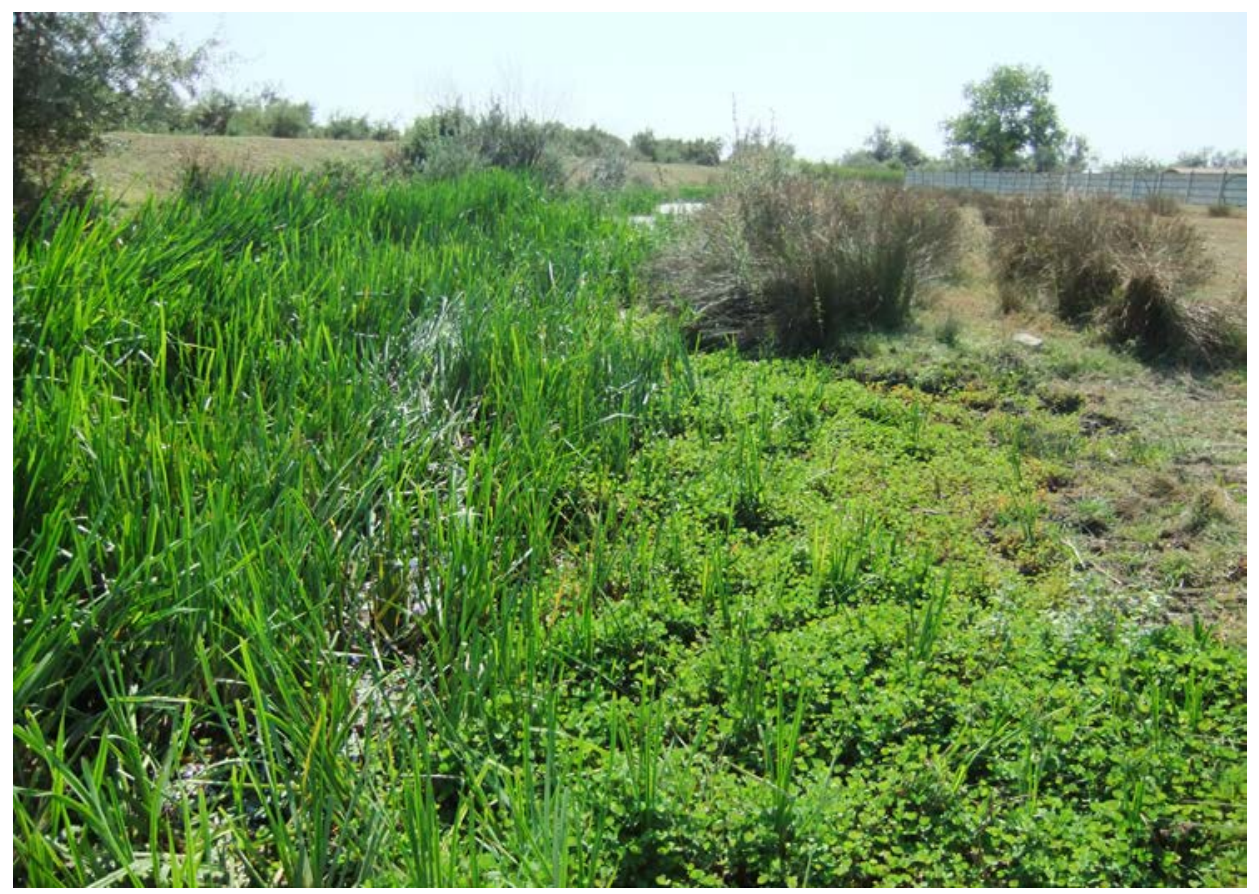

Figure 2: Marsilea quadrifolia stands, terrestrial form, in contact with stands of Sparganium ramosum, Typha angustifolia (on the left side) and Juncus maritimus (right side) on the dune area of Sfântu Gheorghe/Danube Delta near to the coast of the Black Sea (2011). 
Table 2: Marsilea quadrifolia phytocoenoses in the Danube Delta, in the Romanian territory.

\begin{tabular}{|l|c|c|c|c|c|c|c|c|c|c|}
\hline & & & & & & & & & & \\
\hline Number of sample & 1 & 2 & 3 & 4 & 5 & 6 & 7 & 8 & 9 & 10 \\
\hline & & & & & & & terr & terr & terr & terr \\
\hline & & & & & & & & & & \\
\hline Marsilea quadrifolia & 4 & 4 & 4 & 2 & 2 & 3 & 4 & 4 & 4 & - \\
\hline Spirodela polyrhiza & - & 1 & - & 1 & + & + & - & - & - & - \\
\hline Lemna minor & - & + & - & - & + & + & - & - & - & - \\
\hline Salvinia natans & 1 & 1 & + & 2 & 1 & - & - & - & - & - \\
\hline Nymphoides peltata & + & - & - & - & 1 & 2 & - & - & - & - \\
\hline Azolla filiculoides & + & + & - & 3 & 3 & + & - & - & - & - \\
\hline Hydrocharis morsus-ranae & - & - & - & - & + & + & - & - & - & - \\
\hline Lemna trisulca & - & - & - & - & + & - & - & - & - & - \\
\hline Ceratophyllum submersum & - & + & - & - & - & - & - & - & - & - \\
\hline Typha angustifolia & - & + & 1 & + & + & 3 & 1 & + & 1 & - \\
\hline Sparganium ramosum & - & - & 2 & - & - & - & 1 & 1 & - & - \\
\hline Mentha pulegium & - & - & - & - & - & - & - & + & + & - \\
\hline Juncus maritimus & - & - & - & - & - & - & 1 & + & + & 3 \\
\hline Pulicaria dysenterica & - & - & - & - & - & - & - & + & - & + \\
\hline Cynanchum acutum & - & - & - & - & - & - & - & - & 1 & + \\
\hline Limonium meyeri & - & - & - & - & - & - & - & - & + & + \\
\hline Tamarix ramosissima & - & - & - & - & - & - & - & - & - & + \\
\hline & & & & & & & & & & \\
\hline Place and date of sampling & & & & & & & & & & \\
\hline Danube Delta, Sfântu Gheorghe, 06.09 .2011 & & & & & \\
\hline
\end{tabular}

\section{Decline of the species occurrence}

A continuous decline of the populations of Marsilea quadrifolia has been observed in Europe. This is due to human activities producing different changes in the quality of habitat or leading to destruction of the habitat. An important impact has the bank consolidation, undermining of the banks by muskrats (Käsermann, 1999; Pouchol, 2000), drainage and drying-out of waters and characteristic wetlands. The change of management of fishponds, intensification or abandoning of the use is mentioned as one of the important reasons for decreasing of populations of Marsilea quadrifolia (Dehondt et al., 2005). One of the important factors for the decline of the species is water eutrophication and water pollution (Käsermann, 1999; Pouchol, 2000; Shelijag-Sosonka, 1996). The change in agricultural practices with application of herbicides and the eutrophication is given as one of the reasons for the extinction of Marsilea quadrifolia in Spain (Banares et al., 2004). The change of habitat can change the competitive conditions for the species, such are for example shadowing, succession by higher and faster growing vegetation, resulting to the elimination of Marsilea quadrifolia, being disadvantaged with its deficient, low competition capacity in comparison to species with active dispersion.

Tourist activities can also have a negative influence for the sites in which the species are growing (Pouchol, 2000). 
In the concrete case of the decline of the Four leaf water clover in Germany on the river Rhine, are mentioned as causes the rectification of the Rhine in the last centuries, the change of ground water capacity, the filling up of flood channels and other water bodies, the increase of nutrients, herbicides, pesticides, the type of management of waters and wetlands (Waitzmann and Schweizer, 2009). For all the European countries similar causes are mentioned as above discussed.

\section{Conservation status and management}

According to the IUCN 2012 worldwide Red List of threatened species, no major threats have been reported for Marsilea quadrifolia. The species "occurs throughout much of southern Europe east to China and Japan, including Cambodia and Lao PDR. Within Europe it occurs along many of the major river valleys, such are the Loire, Po and parts of the Danube, as well as in complexes of wetlands throughout central and southern Europe” (Gupta, 2012). Therefore the species is listed under the category "Least Concern" (categories and criteria version 3.1), which means widespread and abundant taxa as regards their extent of occurrence, area of occupancy, area extent and/or quality of habitat and number of locations or subpopulations (Gupta, 2012). The comment “widespread and abundant” cannot be taken into account for Europe, as the species is in visible decline, in general with low abundance and extinct in many places (Tab. 3). This is why it has been listed in the Annexes of the Bern Convention and the Flora Fauna Habitat Directive. The category of "least concern" can apply only from the point of view of Asian countries, where it seems the species has a larger distribution and occurs in larger populations.

As Marsilea quadrifolia is known for its low competition capability by changing site conditions (Felföldy, 1990; Dehondt et al., 2005), it is endangered in many sites by extinction or even extinct (Tab. 3).

In the sites with existing localities of Marsilea quadrifolia a continuous monitoring is needed to follow the evolution of the populations and to take appropriate management measures for conservation. The first is to improve the knowledge about management of populations, autecology of the species, colonisation capacity and reproduction biology. It is known, that the sporocarps, which emerge from terrestrial leaves at the time when the banks fall dry, are very resistant and with a long-term germination capacity (Käsermann, 1999; Pouchol, 2000).

In areas with fishponds the change of management from an intensive to more extensive one is needed and is proved in the region of Jura/France and in Switzerland (Käsermann, 1999; Dehondt et al., 2005). Mowing is needed in areas with interferences of Marsilea quadrifolia stands with reed and other tall herbaceous vegetation, to eliminate the shadowing effects, which can be dangerous for the Marsilea stands. Ligneous vegetation taking out is needed too, if it will have negative effects on water clover stands. It is also discussed in relation with the low competition capacity the creation of open soil area for the colonisation of Marsilea quadrifolia in appropriate sites (Radkowitsch, 2007; Pouchol, 2000; Dehondt et al., 2005).

There are usually two ways to assure the conservation of the species. One is to take sporocarps in botanical gardens and cultivate the species ex situ from sporocarps found in some of the sites, allowing possible reintroduction into the wild. The combination of ex situ with in situ cultivation (integrated conservation strategy) seems to be a successful approach. In Spain the species, being extinct in the wild (Banares et al., 2004), is cultivated in the Royal Botanical Garden of Madrid. The reintroduction is promising good results (Aedo et al., 2012). The hope is to obtain stable populations in natural habitats, which can lead to cancel the species from the list of those extinct in the nature. 
Table 3: Red list categories of Marsilea quadrifolia in European countries.

\begin{tabular}{|c|c|c|c|c|c|}
\hline $\begin{array}{c}\text { Red List } \\
\text { Categories }\end{array}$ & $\begin{array}{l}\text { EX, } \\
\text { EW }\end{array}$ & CR & EN & VU & Remarks \\
\hline \multicolumn{6}{|l|}{ Country } \\
\hline Spain & $\mathrm{X}$ & & & & $\begin{array}{l}\text { Cultivated in the Royal Botanical Garden of } \\
\text { Madrid and reintroduced in the Delta of Ebro River } \\
\text { (Aedo et al., 2012) }\end{array}$ \\
\hline Portugal & & $\mathrm{Xr}$ & & & Rare (Dray, 1985); Ramos et al., 1990; ICN, 2006 \\
\hline France & & & & $\mathrm{X}$ & Dehondt, 2005; Dehondt et al., 2005 \\
\hline Switzerland & $(\mathrm{X})$ & & & & $\begin{array}{l}\text { Reintroduced repeatedly in the fishponds at Bonfol } \\
\text { (Jura) without durable success (Käsermann, 1999) } \\
\text { and in Bellechasse }\end{array}$ \\
\hline Italy & & & & $\mathrm{X}$ & Conti et al., 1992 \\
\hline Germany & $(\mathrm{X})$ & & $\mathrm{X}$ & & $\begin{array}{l}\text { Strictly protected species (BfN, 2012; Ludwig and } \\
\text { Schnittler, 1996; Breunig and Demuth, 2000); } \\
\text { reintroduced in the wild with good results } \\
\text { (Radkowitsch, 2007) }\end{array}$ \\
\hline Poland & $(\mathrm{X})$ & & $\mathrm{X}$ & & $\begin{array}{l}\text { Cultivated in the Botanical Garden of Warsaw } \\
\text { University and reintroduced in a pond near } \\
\text { Przemysl (Kazmierczskowa and Zarzycki, 2001; } \\
\text { Zarzycki and Szelag, 1992) }\end{array}$ \\
\hline Austria & & & $\mathrm{X}$ & & $\begin{array}{l}\text { Only in Styria, in all other areas Burgenland, } \\
\text { Upper Austria, Carinthia extinct (Adler et al., } \\
\text { 1994; Käsermann, 1999) }\end{array}$ \\
\hline Slovakia & & & $\mathrm{Xr}$ & & Most vulnerable (Maglocky and Feráková, 1993) \\
\hline Hungary & & & $\mathrm{Xr}$ & & $\begin{array}{l}\text { Protected taxon of Western European importance } \\
\text { (Horváth et al., 1995) }\end{array}$ \\
\hline Croatia & & & $\mathrm{X}$ & & $\begin{array}{l}\text { Borsic: in FCD-Flora Croatica Database 2012; } \\
\text { Ministarstvo Graditelistva i zastite okolisa 1994; } \\
\text { Nikolic, } 1994\end{array}$ \\
\hline $\begin{array}{l}\text { Bosnia- } \\
\text { Herzegovina }\end{array}$ & & & & $\mathrm{X}$ & Silic, 1996 \\
\hline Albania & & & & $\mathrm{X}$ & Vangjeli et al., 1995 \\
\hline Romania & & & & $\mathrm{X}$ & $\begin{array}{l}\text { Oțel } 2000 \text { (data for the Danube Delta); Oprea, } \\
\text { 2005; in the Red data book of the country the } \\
\text { species is not included (Dihoru and Negrean, } \\
\text { 2009); rare species Danube Delta (Ciocârlan, 1994) }\end{array}$ \\
\hline Bulgaria & & & $\mathrm{Xr}$ & & $\begin{array}{l}\text { Dakov, 1984; sporangia conserved in the Spors and } \\
\text { seeds bank of the Botanical Garden Sofia }\end{array}$ \\
\hline Ukraine & & & $\mathrm{Xr}$ & & $\begin{array}{l}\text { Category I in the Ukrainian Red book of plants } \\
\text { (Shelijag-Sosonka, 1996) }\end{array}$ \\
\hline
\end{tabular}

EX = Extinct, EW = Extinct in the wild, $\mathrm{CR}=$ Critically Endangered, EN = Endangered, $\mathrm{VU}=$ vulnerable. The category LR = low risk is not included in the table, as for Marsilea quadrifolia the category is at present without relevance (Walter and Gillett, 1998), $r=$ rare species. The parenthesis of $\mathrm{X}$ in the category of extinct in the wild, means the reintroduction in the wild. 
The species Marsilea quadrifolia has disappeared from the known locations in Germany. Sporocarps were collected from the last confirmed location in waters of a gravel extraction place near Lahr/Offenburg and initiated with this a "conservation culture" in the area of Botanical Garden of University of Karlsruhe (Radkowitsch, 2006). The programme of ex situ cultivation permitted obtaining specimens of Marsilea quadrifolia species, which has been reintroduced in the wild South of Karlsruhe in the former floodplain of the Rhine Rivwe near Rheinstetten in the site of "Rösteläcker". The ex situ cultivation programme included also the foundation of a pig farm, the animals having the role to create open, vegetation free soil patches with a high diversity of macro- and microhabitats for the development of Marsilea quadrifolia being a species with low competition capability (Radkowitsch, 2007).

The implementation and monitoring of the reintroduction of Marsilea quadrifolia have been realised within the framework of a LIFE project "Living floodplains of the Rhine" ongoing from 2005 with efficiency control of the measures in the following two years (Radkowitsch, 2006; 2007).

In the frame of the elaboration of the Management Plan for the Natura 2000 Site "Floodplain of the Rhine between Iffezheim and Karlsruhe", sampling of phytocoenoses edified by Marsilea quadrifolia (experimental plots four and five) were taken in July 2009 (Tab. 1). The samples document a satisfying evolution of the species population and also the development of the whole plant community with the characteristic species combination for the alliance Nanocyperion, for which the species is mentioned as being characteristic and also for phytocoenoses of plant communities included in the class Potamogetonetea.

But in the same time the monitoring clearly demonstrates near the successful reintroduction also the need for further monitoring and management, as recently there has been observed an increasing presence of Potamogeton nodosus. This species with higher competition capacity can become dangerous for the water clover (Marsilea quadrifolia) as a species of low competition capacity (Felföldy, 1990; Dehondt et al., 2005; Käsermann, 1999).

Ex situ conservation has been practised also in Switzerland territory, sporocarps from the Jura region in France have been cultivated and then reintroduced into the wild near Bellechasse. Ex situ conservation cultures were also created in the Botanical Garden of Warsaw University in Poland from where the species has been reintroduced into a pond near Przemysl (Kazmierczskowa and Zarzycki, 2001; Zarzycki and Szelag, 1992).

In Bulgaria where the species Marsilea quadrifolia is considered as endangered and rare, sporangia of it were introduced and conserved in the Spores and Seeds Bank of the Botanical Garden in Sofia, to be used in the future, if the decline of the species will progress.

All these efforts demonstrate that the species Marsilea quadrifolia requires special attention for conservation with appropriate measures, direct in sites where has been found the species in times before, but also in ex situ conservation cultures, which have an important role to assure survival in sites where the species is in decline, near to extinction or extinct. 


\section{CONCLUSIONS}

It is clear that in European countries Marsilea quadrifolia is a species in decline due to human interventions in different ways, and needs in many cases a strict protection. This fact corresponds nearly for all European countries with the consequence that the species is listed in all Red lists and Red Data books of threatened flora in the conservation categories Extinct in the Wild, Extinct, Critically Endangered, Endangered and Vulnerable.

The low concurrence competition capacity and the low capacity of spread and colonising new sites are possibly the main factors for the decline of the species. On the other side the longevity of sporocarps which are resistant to drying-out, can lead to a reactivation of populations in sites where the species is considered as extinct, if the site conditions are again appropriate for evolution of the species. But in the most cases the reoccurrence in the same place, from which the species disappeared years ago is not possible, as many habitats have been unrecoverable destroyed by human interventions.

In the countries where the species is extinct in the wild, many efforts are being made to reintroduce the species into the wild. Successes in this direction have been achieved and offer promise for further reintroduction measures.

\section{ACKNOWLEDGEMENT}

Thanks to Wackerhagen C. from the University of Konstanz, who completed successfully an internship at the Division WWF- Auen-Institute of the Institute for Geography and Geoecology, KIT University of Karlsruhe, for her help with literature research. 


\section{REFERENCES}

1. Adler W., Oswald K. and Fischer R., 1994 - Exkursionsflora von Österreich, Verlag Eugen Ulmer Stuttgart und Wien, 1180 (Marsilea quadrifolia). (in German)

2. Aedo C., Medina L. and Fernández M., 2012 - Plantas extinguidas de la flora espanola, Quercus, 321, 11, 42-48. (in Spanish)

3. Banares A., Blanca G., Güemes J., Moreno J. C. and Ortiz S. (eds), 2004 - Atlas y libro Rojo de la Flora Vascular Amenanzada de Espana, Dirección General de Conservación de la Naturaleza, Madrid, 1069. (in Spanish)

4. Banares A., Blanca G., Güemes J., Moreno J. C. and Ortiz S., 2010 - Atlas y Libro Rojo de la Flora Vascular Amenazada de Espana, Adenda 2010, Dirección General de Medio Natural y Politica Forestal (Ministerio de Media Ambiente y Medio Rural y Marino) - Sociedad Espanola de Biologia de la Conservacion de Plantas, Madrid, 170 (Marsilea strigosa). (in Spanish)

5. Benedek A.-M., Drăgulescu C., Frink J. P. and Petrovici M., 2012 - Flora and habitats of Cefa Nature Park (Crişana, Romania), Transylvanian Review of Systematical and Ecological Research, The Cefa Nature Park, Curtean-Bănăduc et al. (eds), 13, 35-68, Sibiu.

6. Borsic I., 2012 - Marsilea quadrifolia L., in Flora Croatica Database, Vascular Plants Taxonomy and Bibliography of Croatian Flora, Crvena knjiga, http://hirc.botanic.hr/fcd

7. Botanix, 2012 - The cultivation of the Four leaf Clover (Marsilea quadrifolia), Botanix - A journal about plants and gardening, www.botanix.kpr.eu/en/index.php?text=15-thecultivation-of-the-four-leaf-clover-marsilea-quadrifolia

8. Breunig T. and Demuth S., 2000 - Rote Liste der Farn- und Samenpflanzen BadenWürttemberg, Landesanstalt für Umweltschutz Baden-Württemberg Herausgeber, Fachdienst Naturschutz, Naturschutzpraxis, Artenschutz 2, 160, 3, Neu bearbeitete Fassung (Stand 15.4.1999). (in German)

9. Bundesamt für Naturschutz BfN, 2012 - Flora Web. Bonn, floraweb.de

10. Conti F., Manzi A. and Pedrotti F., 1992 - Libro rosso delle piante d'Italia, WWF Italia in collaborazione con la Società Botanica Italiana, 637. (in Italian)

11. Cook C. D. K., 1996 - Aquatic plant book, SPB Academic Publishing, Amsterdam/New York, 228.

12. Dakov M. (ed.), 1984 - Tshervena kniga na NR Bulgaria, Red data book of the People's Republic of Bulgaria, 1, Rastenia/Plants, Publishing house of the Bulgarian Academy of Sciences, Sofia, 442 (Marsilea quadrifolia). (in Bulgarian)

13. Dehondt F., Ferrez Y. and Guyonneau I., 2005 - Connaissance de la flore rare ou menacée de Franche-Comté, Marsilea quadrifolia L., CBFC Conservatoire botanique de Franche-Comté, 19, Besancon. (in French)

14. Dihoru G. and Negrean G., 2009 - Red Book of Vascular Plants of Romania, Editura Academiei Române, Bucureşti, 630.

15. Dray A. M., 1985 - Plantas a proteger em Portugal Continental, Servico Nacional de Parques, Reservas e Conservacao da Natureza, Lisboa, 56. (in Portuguese)

16. Felföldy L., 1990 - Hinár határozó, (Marsilea), Budapest, Vizügyi Hidrobiológia, 18, 144. (in Hungarian)

17. Garcia M. P., Frenández Z. R., Cirujano S. and Sousa A., 2006 - Aquatic macrophytes in Donana protected area (SW Spain), Limnetica, 25, 1-2, 71-80.

18. Gupta A. K., 2012 - Marsilea quadrifolia L., in IUCN 2012, Red List of Threatened Species, Version 2012.2. www.iucnredlist.org/details/161864/0

19. Haeupler H. and Schönfelder P., 1988 - Atlas der Farn- und Blütenpflanzen der Bundesrepublik Deutschland, Eugen Ulmer Verlag Stuttgart, 768 (Marsilea quadrifolia). (in German) 
20. Horváth F., Dobolyi Z. K., Morschhauser T., Lökös L., Karas L. and Szerdahelyi T., 1995 Flóra adatbázis 1.2, Taxonlista és attribútum-állomány, Hungarian Academy of Sciences, Vácrátot, 267. (in Hungarian)

21. Husák S. and Otahelová H., 1986 - Contribution to the ecology of Marsilea quadrifolia L., Folia Geobotanica et Phytotaxonomica, Praha, 21, 85-89.

22. ICN, 2006 - Plano Sectorial da Rede Natura 2000, Flora, Marsilea quadrifolia, Lisboa, www.icn.pt/psrn2000/pdfs/flora

23. IUCN, 2012 - The IUCN Red List of threatened species 2012.2, www.iucnredlist.org

24. Kazmierczakowa R. and Zarzycki K. (eds), 2001 - Polish Red Data Book of Plants. Pteridophytes and flowering plants, Polish Academy of Science, W. Szafer Institute of Botany and Institute of Nature Conservation, Cracow, 664 (Marsilae quadrifolia).

25. Käsermann C., 1999 - Merkblätter Artenschutz - Blütenpflanzen und Farne (Stand Oktober 1999), 196-197, BUWL/SKEW/PRONATURA. (in German)

26. Landolt E., 1991 - Gefährdung der Farn- und Blütenpflanzen in der Schweiz mit gesamtschweizerischen und regionalen roten Listen, Bundesamt für Umwelt, Wald und Landschaft (BUWAL), Bern, 185 (Marsilea quadrifolia). (in German)

27. Ludwig G. and Schnittler M. (eds) BfN (Hrsg.), 1996 - Rote Liste gefährdeter Pflanzen Deutschlands, Schriftenreihe für Vegetationskunde 28, Bundesamt für Naturschutz, BonnBad Godesberg, 744. (in German)

28. Maglocky S. and Ferákova V., 1993 - Red list of ferns and floweing plants (Pteridophyta and Spermatophyta) of the flora of Slovakia (the second draft), Biologia Bratislava, 48, 4, 361385.

29. Ministarstvo Graditelistva i zastite okolisa, 1994 - Crvena Knijiga biljnik vrsta Republike Hrvatsko, Zavod za Zastitu Prirode, Zagreb, 522. (in Croatian)

30. Nikolic T. (ed.), 1994 - Flora Croatica, Index Florae Croaticae, 1, Natura Croatica, 3, Supplement 2, 1-116.

31. Oberdorfer E., 2001 - Pflanzensoziologische Exkursionsflora für Deutschland und angrenzende Gebiete, Verlag Eugen Ulmer Stuttgart, 8, Aufl., 1051 (Marsilea quadrifolia). (in German)

32. Oprea A., 2005 - Lista critică a plantelor vasculare din România, Edit. Universităţii “Alexandru Ioan Cuza" Iaşi, 668. (in Romanian)

33. Oțel V. (ed.), 2000 - The Red List of plant and animal species from the Danube Delta Biosphere Reserve Romania, Institutul Naţional de Cercetare-Dezvoltare Delta Dunării/Danube Delta National Institute, edited by Fundatia Aves, 132.

34. Philippi G., 1969 - Zur Verbreitung und Soziologie einiger Arten von Zwergbinsen- und Strandlingsgesellschaften im badischen Oberrheingebiet, Mitteilungen des Badischen Landesvereins für Naturkunde, Naturschutz N. F., 10, 139-172. (in German)

35. Pouchol S., 2000 - Steckbrief: Kleefarn - Marsilea, WWF Schweiz, http:// www.villege.ch/cjb/rsf/fra/fiches/pdf/mars_quad_f.pdf; assets.wwf.ch/custom/arten/Kleefarn.pdf

36. Radkowitsch A., 2006 - Life - Effizienzkontrolle Schweinebeweidung von MarsileaWuchsorten, Projekt Life Rheinauen, Zwischenbericht, Regierungspräsidium Karlsruhe Ref., 56, 23. (in German)

37. Radkowitsch A., 2007 - Life - Effizienzkontrolle Schweinebeweidung von MarsileaWuchsorten, Projekt Life Rheinauen, Zwischenbericht, Regierungspräsidium Karlsruhe Ref., 56, 25. (in German)

38. Ramsar Information Sheet, 1998 - Greece Ramsar Site 58 (WI Site 3 GR006), A Directory of Wetlands of International Importance, www.wetlands.org/RSIS/_COP9Directory/ Directory/3GR006.html 
39. Schneider E., Nichersu I., Knoben R., Koppelman G., Chendres V., Tatole V. and Keukelaar F. (eds), 2005 - Protection of wetlands of the Danube, A pilot project for Cama-Dinu islets area, Final Report, project realised for the Ministerul Mediului şi a Gospodăririi Apelor România (Ministry of Environment and Water Management) by DDNI, WWF Germany, Apele Române, Royal Haskoning PHARE RO 0105 Cross Border Cooperation Programme Romania-Bulgaria.

40. Shelijag-Sosonka I. R., 1996 - Tshervona kniga Ukraini, Roslinnii Svit. Nationalna Akademija Nauk Ukraini/Red book of Ukraine, Flowering plants, Ukrainian Academy of Science, Kiev, 603 (Marsilea quadrifolia). (in Ukrainian)

41. Silic C., 1996 - Spisak Biljnik vrsta (Pteridophyta I Spermatophyta) ZA Crvenu Knjigu Bosne i Hercegovine/The list of the vegetable species (Pteridophyta and Spermatophyta) FOR, The "Red Book" of Bosnia and Hercegovina, Sarajevo, 367. (in Croatian)

42. Tahtadjian A. L., Geltman D. W. and Popova T. N. (eds), 1988 - Krasnaija kniga RSFSR, Rastenija, Akad. Nauk SSSR, Moskva, 590 (Marsilea), (in Russian)

43. Topa E., 1952 - Fam. Marsileaceae R. Br. in Flora Republicii Populare Române, I, Editura Academiei Republicii Populare Române, 150-152.

44. Vangjeli J., Ruci B. and Mullaj A., 1995 - Red Book, Threatened and rare plants species of Albania, Acad. of Science Institute of Biological Research, Tirana, 169.

45. Walter K. S. and Gillett H. (eds), 1998, 1997 - IUCN Red List of Threatened Plants, IUCN The World Conservation Union, 862 (Marsileaceae).

46. Zarzycki K. and Szelag Z., 1992 - Red list of threatened vascular plants in Poland, in Zarzycki K., Wojewoda W. and Heinrich Z. (eds) - List of threatened plants in Poland, Second edition, Polish Academy of Sciences, W. Szafer Institute of Botany, Cracow, 87-98. 